\title{
MULTIGENE EVIDENCE REVEALS THE SYSTEMATIC POSITION OF PLEUROCLADOPSIS SIMULANS (C. MASSAL.) R. M. SCHUST. WITHIN SCHISTOCHILA DUMORT., SCHISTOCHILACEAE
}

\author{
XiaOlan He \& Yu SuN
}

\begin{abstract}
The monotypic Pleurocladopsis, endemic to Chile, was established by Schuster in 1964 based on an earlier poorly known species Cephalozia (?) simulans C. Massal. The phylogenetic position of Pleurocladopsis simulans had been considered uncertain until it was placed in the family Schistochilaceae on account of the gynoecial and sporophytic characters. It has been assumed that Pleurocladopsis represents the starting point of evolution in Schistochilaceae. In the present study, the phylogenetic position and taxonomic status of Pleurocladopsis simulans are inferred from phylogenetic analysis of three chloroplast DNA sequence data. The result suggests that the genus was established solely based on the autapomorphic characters, thus obscuring its actual phylogenetic relationship with Schistochila and that these characters are later derived rather than ancestral. The result also confirms that the gynoecial and sporophytic characters are important in taxonomy, but they may be not sufficient at the infrafamilial level and at other lower taxonomic levels. In accordance with the results of the present study, Pleurocladopsis is synonymised with Schistochila, and the new combination Schistochila simulans (C. Massal.) Xiao L. He \& Yu Sun is made.
\end{abstract}

Key words: autapomorphy, Chile, DNA sequence, endemics, liverwort, molecular phylogeny, morphology, Pleurocladopsis simulans, Schistochila, Schistochilaceae, systematics, taxonomy

Xiaolan He \& Yu Sun, Botanical Museum, Finnish Museum of Natural History, University of Helsinki, P.O. Box 7, FIN-00014 Helsinki, Finland; e-mail: xiao-lan.he@helsinki.fi

\section{INTRODUCTION}

The genus Pleurocladopsis R. M. Schust. has been thought to be a perfect example demonstrating the importance of the role of gynoecial and sporophytic characters in liverwort taxonomy (Schuster 1971). The monotypic Pleurocladopsis, endemic to Chile, was established by Schuster in 1964 (Schuster 1964a) based on an earlier poorly known species Cephalozia (?) simulans C. Massal. (Massalongo 1885). The phylogenetic position of Pleurocladopsis simulans (C. Massal.) R. M. Schust. had been considered uncertain until it was placed in the family Schistochilaceae on account of the gynoecial and sporophytic characters (Schuster 1972). Schuster (1972) assumed that the family Schistochilaceae possibly evolved directly from Pleurocladopsis-like ancestors based on the characters present in Pleurocladopsis, such as the tristichous and nearly isophyllous leaf organization and the bracteolar antheridia. However, this assumption has not been tested by evidence other than that derived from morphology. Results from recent studies on the molecular systematics of the liverworts have rejected the presumption that isophylly represents the starting point of leafy liverwort evolution; on the contrary, it has been shown to be a derived character which has evolved several times independently in various leafy lineages (e.g., He-Nygrén et al. 2004, 2006).

Massalongo (1885) described a sterile liverwort as Cephalozia (?) simulans under a new section Pleurocladotypus of which the general aspect resembles Pleuroclada albescens (Hook.) Spruce within a broadly defined Cephalozia (Dumort.) Dumort. Stephani (1898-1924) placed it without question in Cephalozia. However, various gametophytic features of the species including erect and nearly isophyllous organization with large underleaves approaching the lateral leaves in size and 
shape, the entirely lateral branching, the shallowly bilobed leaves and the leaf cells with coarse, nodose to triradiate trigones are markedly different from those of Cephalozia and Cephaloziaceae. These differences had led Schuster (1964a) to assign the species to a new genus Pleurocladopsis, but he failed to recognize its position within established families based on available gametophytic characters. Schuster (1966) later placed it tentatively in the family Herbertaceae on account of characters such as tristichous leaf organization, bilobed leaves and well-developed trigones of the leaf cells. The uncertainty of the phylogenetic position of the species persisted until the discovery of fertile material with sporophytes, revealing its close affinity to the complicate-bilobed and distichous Schistochilaceae (Schuster 1971)! Based on the shared characters, including the scattered purplish rhizoids, the presence of a coelocaule of the gynoecium, the sporophyte capsule shape and wall thickening patterns, and also spore and elater anatomy, Schuster (1971) conclusively placed Pleurocladopsis in Schistochilaceae and later elevated it as an independent subfamily Pleurocladopsidoideae corresponding to another subfamily Schistochiloideae possessing a distichous leaf organization (Schuster 1972; Schuster \& Engel 1977, 1985; Hässel de Menéndez \& Rubies 2009). A different opinion was offered by Solari (1971), whereby she proposed a new family Pleurocladopsidaceae to accommodate Pleurocladopsis simulans C. Massal. alone under the suborder Herbertineae. This arrangement was supported by Grolle (1972).

Schuster (1964b) suggested the close affinities between Schistochilaceae and Perssoniellaceae and the two families were proposed to constitute the suborder Perssoniellineae. However, the sole species of the Perssoniellaceae, Perssoniella vitreocincta Herzog, endemic to New Caledonia, with a series of unique morphological characters, has recently been transferred to Schistochila based on DNA sequence evidence. From He and Glenny (2010), who showed that the phylogenetic signal present in morphological data can be diminished by remarkable autapomorphic evolution, and that higher-level taxa whose distinctness rests on autapomorphies should be treated with caution and that independent evidence of their special systematic position is needed.

In the present study, the phylogenetic position and taxonomic status of Pleurocladopsis simulans are inferred from phylogenetic analysis of three chloroplast DNA sequence data. We aim to answer the following questions: Does Pleurocladopsis simulans represent an isolated lineage as an archaic species representing the starting point of evolution within Schistochilaceae? Is Pleurocladopsis deserving of family rank, that is, as belonging to an independent family, Pleurocladopsidaceae? What is the natural systematic position of the taxon? Is there any phylogenetic information on the systematic position of the species that could not be revealed by morphological evidence alone?

\section{MATERIALS AND METHODS}

TAXON SAMPLING FOR PHYLOGENETIC ANALYSES

For the present study, a specimen of Pleurocladopsis simulans was collected by the senior author in 2012 at Alberto de Agostini National Park, Cape Horn Biosphere Reserve, Chile. The plant grows on a dripping cliff wall, intermixed with Schistochila splachnophylla (Hook. f. \& Taylor) Stephani and other bryophyte species. In total, 55 exemplars including Pleurocladopsis simulans and other 53 Schistochilaceae taxa as ingroup and Ptilidium pulcherrimum (F. Weber) Hampe as outgroup were included for phylogenetic analyses. The selection of the outgroup was done based on the study of He and Glenny (2010). The ingroup included a DNA sequence dataset obtained from three chloroplast DNA regions, $r b c \mathrm{~L}, r p s 4$, and $t r n \mathrm{~L}-\mathrm{F}$, for all 55 species, except trnL-F sequences of Schistochila aligera (Nees \& Blume) J. B. Jack \& Stephani, and the $r b c \mathrm{~L}$ sequences of $S$. balfouriana (Hook. f. \& Taylor) Stephani, S. cristata Stephani, S. leucophylla (Lehm.) Stephani, S. nitidissima R. M. Schust., S. parvistipula Rodway, S. reflexistipula J. J. Engel \& R. M. Schust., S. spegazziniana (C. Massal.) Stephani, S. sp. and S. stratosa (Mont.) A. Evans, which unfortunately could not be obtained for this study. Novel rps 4 sequences for 29 species, $t r n \mathrm{~L}-\mathrm{F}$ sequences for 28 species and $r b c \mathrm{~L}$ sequences for 20 species were generated in this study. Their sequence accession numbers are in italics in Table 1. Table 1 also provided information of the full species names of the samples used. 
Table 1. List of taxa, GenBank accession numbers and sequence sources for $r b c \mathrm{~L}, r p s 4$ and $t r n \mathrm{~L}-\mathrm{F}$ sequences used in the present study. Accession numbers for novel sequences generated in this study are in Italics.

\begin{tabular}{|c|c|c|c|c|}
\hline \multirow{2}{*}{ Species } & \multicolumn{3}{|c|}{ Genbank accession number } & \multirow{2}{*}{ Voucher or sequence source } \\
\hline & $r b c \mathrm{~L}$ & rps 4 & $\operatorname{trn} \mathrm{L}-\mathrm{F}$ & \\
\hline Ptilidium pulcherrimum (F. Weber) Hampe & AY302460 & AY462388 & AY251186 & He-Nygrén at al. 2004 \\
\hline $\begin{array}{l}\text { Pleurocladopsis simulans (C. Massal.) } \\
\text { R. M. Schust. }\end{array}$ & KF184391 & KF184411 & KF184440 & Chile, He $2928(\mathrm{H})$ \\
\hline Schistochila acuminata Stephani & KF184392 & KF184412 & KF184441 & Malaysia, Bell $19(\mathrm{H})$ \\
\hline Schistochila alata (Lehm.) Stephani & KF184393 & $K F 184413$ & KF184442 & Chile, Hyvönen $2805(\mathrm{H})$ \\
\hline $\begin{array}{l}\text { Schistochila aligera (Nees \& Blume) } \\
\text { J. B. Jack \& Stephani }\end{array}$ & KF184394 & $K F 184414$ & - & Indonesia, Gradstein 11061 (GOET) \\
\hline Schistochila antara Grolle & $K F 184395$ & $K F 184415$ & $K F 184443$ & $\begin{array}{l}\text { Papua New Guinea, Norris } \\
59752(\mathrm{H})\end{array}$ \\
\hline $\begin{array}{l}\text { Schistochila appendiculata (Hook.) Dumort. } \\
\text { ex Trevis. }\end{array}$ & AY462328 & AY462394 & AY463596 & He-Nygrén et al. 2004 \\
\hline $\begin{array}{l}\text { Schistochila berggrenii (J. J. Engel \& R. M. } \\
\text { Schust.) Xiao-L. He \& Glenny }\end{array}$ & GU733922 & GU733964 & GU733943 & He \& Glenny 2010 \\
\hline $\begin{array}{l}\text { Schistochila balfouriana (Hook. f. \& Taylor) } \\
\text { Stephani }\end{array}$ & - & $K F 184416$ & KF184444 & New Zealand, He $2262(\mathrm{H})$ \\
\hline Schistochila blumei (Nees) Trevis. & GU733936 & GU733978 & GU733957 & He \& Glenny 2010 \\
\hline $\begin{array}{l}\text { Schistochila childii (R. M. Schust. } \\
\quad \text { \& J. J . Engel) Xiao-L. He \& Glenny }\end{array}$ & GU733923 & GU733965 & GU733944 & He \& Glenny 2010 \\
\hline $\begin{array}{l}\text { Schistochila chlorophylla (Col.) J. J. Engel } \\
\quad \text { \& R. M. Schust. }\end{array}$ & GU733932 & GU733974 & GU733953 & He \& Glenny 2010 \\
\hline Schistochila ciliata (Mitt.) Stephani & GU733937 & GU733979 & GU733958 & He \& Glenny 2010 \\
\hline Schistochila colensoana Stephani & GU733924 & GU733966 & GU733945 & He \& Glenny 2010 \\
\hline $\begin{array}{l}\text { Schistochila conchophylla E. A. Hodgs. } \\
\text { \& Allison }\end{array}$ & GU733929 & GU733971 & GU733950 & He \& Glenny 2010 \\
\hline Schistochila cristata Stephani & - & $K F 184417$ & KF184445 & Australia, Streimann $27437(\mathrm{H})$ \\
\hline Schistochila doriae (De Not.) Trevis. & GU733938 & GU733980 & GU733959 & He \& Glenny 2010 \\
\hline Schistochila gayana (Gott.) Stephani & GU733939 & GU733981 & GU733960 & He \& Glenny 2010 \\
\hline Schistochila glaucescens (Hook.) A. Evans & GU733940 & GU733982 & GU733961 & He \& Glenny 2010 \\
\hline Schistochila kirkiana Stephani & GU733941 & GU733983 & GU733962 & He \& Glenny 2010 \\
\hline Schistochila lamellata (Hook.) Dumort. & KF184396 & KF184418 & KF184446 & Chile, Hyvönen 5945 (H) \\
\hline $\begin{array}{l}\text { Schistochila laminigera (Hook. f. \& Taylor) } \\
\text { A. Evans }\end{array}$ & AY462329 & AY462395 & AY463586 & He-Nygrén et al. 2004 \\
\hline $\begin{array}{l}\text { Schistochila lehmanniana (Lindenb.) Car- } \\
\text { rington \& Pearson }\end{array}$ & GU733933 & GU733975 & GU733954 & He \& Glenny 2010 \\
\hline Schistochila leucophylla (Lehm.) Stephani & - & $K F 184419$ & $K F 184447$ & Chile, He $3349(\mathrm{H})$ \\
\hline Schistochila monticola R. M. Schust. & KF184397 & KF184420 & KF184448 & New Zealand, Glenny 9923 (H) \\
\hline Schistochila muricata E. A. Hodgs. \& Allison & KF184398 & KF184421 & KF184449 & New Zealand, Glenny $10243(\mathrm{H})$ \\
\hline Schistochila nitidissima R. M. Schust. & - & $K F 184422$ & $K F 184450$ & New Zealand, Glenny 10505 (H) \\
\hline $\begin{array}{l}\text { Schistochila nivicola (R. M. Schust. } \\
\quad \text { \& J. J. Engel) Xiao-L. He \& Glenny }\end{array}$ & GU733925 & GU733967 & GU733946 & He \& Glenny 2010 \\
\hline Schistochila nobilis (Hook.) Trevis. & KF184399 & $K F 184423$ & $K F 184451$ & New Zealand, He $2174(\mathrm{H})$ \\
\hline Schistochila nuda Horik. & AY462297 & AY462351 & AY463558 & He-Nygrén et al. 2004 \\
\hline Schistochila parvistipula Rodway & - & $K F 184424$ & KF184452 & New Zealand, Glenny 8903 (H) \\
\hline
\end{tabular}


Table 1. Continued.

\begin{tabular}{|c|c|c|c|c|}
\hline \multirow{2}{*}{ Species } & \multicolumn{3}{|c|}{ Genbank accession number } & \multirow{2}{*}{ Voucher or sequence source } \\
\hline & $r b c \mathrm{~L}$ & $r p s 4$ & $\operatorname{trn} \mathrm{L}-\mathrm{F}$ & \\
\hline $\begin{array}{l}\text { Schistochila pellucida } \text { R. M. Schust. } \\
\quad \text { \& J. J. Engel }\end{array}$ & KF184400 & KF184425 & KF184453 & New Zealand, Glenny $7283(\mathrm{H})$ \\
\hline Schistochila pinnatifolia (Hook.) R. M. Schust. & GU733930 & GU733972 & GU733951 & He \& Glenny 2010 \\
\hline $\begin{array}{l}\text { Schistochila philippinensis (Mont.) J. B. Jack } \\
\quad \text { \& Stephani }\end{array}$ & KF184401 & KF184426 & KF184454 & Sri Lanka, He $2051(\mathrm{H})$ \\
\hline $\begin{array}{l}\text { Schistochila pluriciliata } \text { R. M. Schust. } \\
\quad \text { \& J. J. Engel }\end{array}$ & $K F 184402$ & KF184427 & $K F 184455$ & New Zealand, Glenny $9815(\mathrm{H})$ \\
\hline Schistochila pseudociliata R. M. Schust. & GU733934 & GU733976 & GU733955 & He \& Glenny 2010 \\
\hline Schistochila quadrifida A. Evans & $K F 184403$ & $K F 184428$ & $K F 184456$ & Chile, Hyvönen 2744 (H) \\
\hline Schistochila reflexa (Mont.) Stephani & KF184404 & $K F 184429$ & $K F 184457$ & Argentina, Hyvönen 3045 (H) \\
\hline $\begin{array}{l}\text { Schistochila reflexistipula J. J. Engel } \\
\quad \text { \& R. M. Schust. }\end{array}$ & - & KF184430 & $K F 184458$ & Chile, He $2943(\mathrm{H})$ \\
\hline $\begin{array}{l}\text { Schistochila repleta (Hook. f. \& Taylor) } \\
\text { Stephani }\end{array}$ & KF184405 & KF184431 & KF184459 & New Zealand, Glenny 9722 (H) \\
\hline Schistochila schultzei Stephani & KF184406 & $K F 184432$ & KF184460 & $\begin{array}{l}\text { Papua New Guinea, Hoffman 90-92 } \\
\text { (H) }\end{array}$ \\
\hline Schistochila sciophila R. M. Schust. & KF184407 & KF184433 & $K F 184461$ & Chile, Larraín \& Andrus $31210(\mathrm{H})$ \\
\hline Schistochila sciurea (Nees) Schiffn. & GU733935 & GU733977 & GU733956 & He \& Glenny 2010 \\
\hline Schistochila $\mathrm{sp}$ & - & KF184434 & $K F 184462$ & Chile, Engel $11872(\mathrm{H})$ \\
\hline $\begin{array}{l}\text { Schistochila spegazziniana (C. Massal.) } \\
\text { Stephani }\end{array}$ & - & KF184435 & $K F 184463$ & Chile, He 3292 (H) \\
\hline Schilstochila sphagnoides (Schwägr.) Stephani & KF184408 & KF184436 & KF184464 & Madagascar, Pócs 9481/N (H) \\
\hline $\begin{array}{l}\text { Schistochila splachnophylla (Hook. f. } \\
\quad \& \text { Taylor) Stephani }\end{array}$ & KF184409 & KF184437 & $K F 184465$ & Chile, $\mathrm{He} 3213(\mathrm{H})$ \\
\hline Schistochila stratosa (Mont.) A. Evans & - & KF184438 & KF184466 & Chile, Larraín \& Vargas 26565 (H) \\
\hline Schistochila subhyalina R. M. Schust. & GU733926 & GU733968 & GU733947 & He \& Glenny 2010 \\
\hline Schistochila tasmanica Stephani & GU733942 & GU733984 & GU733963 & He \& Glenny 2010 \\
\hline Schistochila trispiralis R. M. Schust. & GU733927 & GU733969 & GU733948 & He \& Glenny 2010 \\
\hline $\begin{array}{l}\text { Schistochila tuloides (Hook. f. \& Taylor) } \\
\text { R. M. Schust. }\end{array}$ & AY462321 & AY462381 & AY463581 & He-Nygrén et al. 2004 \\
\hline Schistochila virescens R. M. Schust. & GU733928 & GU733970 & GU733949 & He \& Glenny 2010 \\
\hline $\begin{array}{l}\text { Schistochila vitreocincta (Herzog) Xiao-L. He } \\
\quad \text { \& Glenny }\end{array}$ & GU733931 & GU733973 & GU733952 & He \& Glenny 2010 \\
\hline Schistochila volans Grolle & KF184410 & KF184439 & KF184467 & $\begin{array}{l}\text { Papua New Guinea, De Sloover } \\
43.056(\mathrm{H})\end{array}$ \\
\hline
\end{tabular}

\section{DNA EXTRACTION, PCR AMPLIFICATION AND SEQUENCING}

DNA was extracted from dry herbarium material, using the Invisorb Spin Plant Mini Kit (Invitek, Berlin, Germany). DNA amplification and sequencing were performed using the protocol in He-Nygrén et al. (2004). Of the three molecular regions examined, $r b c \mathrm{~L}$ and $r p s 4$ are protein-coding genes so there is no length variation in the sequences obtained. In the present study, the length of $r b c \mathrm{~L}$ sequences was $1000 \mathrm{bp}$, and of $r p s 4573 \mathrm{bp}$. The $\operatorname{trn} \mathrm{L}-\mathrm{F}$ region contains a partial sequence of the leucine transfer $\mathrm{RNA}_{(\mathrm{UAA})}$, an intergenic spacer, and a partial sequence of phenylalanine $\operatorname{tRNA}_{(\mathrm{GAA})}$. The length of the sequences varied from 446 bp (Schistochila tuloides) to 589 bp (Schistochila splachnophylla largely due to 
differences in the length of the variable regions and the intergenic spacer. Alignment of the $t r n \mathrm{~L}-\mathrm{F}$ region was done using MUSCLE (Edgar 2004), and the length of the aligned characters was $791 \mathrm{bp}$.

\section{PHYLOGENETIC ANALYSES}

The dataset of the 55-exemplar $r b c \mathrm{~L}, r p s 4$, and $\operatorname{trn} \mathrm{L}-\mathrm{F}$ sequence matrix was analyzed using Bayesian inference. In total, 2409 aligned characters were included in the combined dataset. For the phylogenetic analyses, using MrBayes version 3.2.1 (Huelsenbeck \& Ronquist 2001; Ronquist 2004; Ronquist et al. 2012), the combined data were partitioned into three sets corresponding to the $r b c \mathrm{~L}, r p s 4$ and $t r n \mathrm{~L}-\mathrm{F}$ regions. Three separate runs, each including 10 million generations with four chains and sampling trees and parameters every 100th generation, were completed. Compartments were unlinked to allow the parameters to vary independently. The analyses were performed under the GTR $+\mathrm{I}+\mathrm{G}$ model which was used for each of the three partitions within each data set based on the estimates using MrModeltest v. 2.3 (Nylander 2004; Swofford 2002). All sample points prior to stability were discarded as burn-in values, and the remaining points were used to generate a $50 \%$ majority consensus tree.

\section{RESULTS}

All three sequenced regions were initially analyzed separately. Congruence between datasets was evaluated by visual comparison of the topologies and levels of clade support arrived at the Bayesian analysis. Bayesian inferences based on the combined data set resolve Pleurocladopsis simulans as nested within a well-supported clade consisting of Schistochila spegazziniana, and closely related $S$. conchophylla and $S$. pinnatifolia (Fig. 1). They together were grouped in a well-supported clade including the South American sister group S. alata and S. gayana, the New Zealand sister group S. nobilis and S. pluriciliata, as well as all the tropical southeastern Asian and Oceanian species (clade IV). P. simulans and all the species of Schistochila formed a monophyletic group, including clade IV and other three well-supported groups, namely clades I, II, and III (Fig. 1). Clade I includes Schistochila sciophila, S. glaucescens and S. sciurea, and clade II S. lamellata, S. appendiculata, S. lehman- niana, S. balfouriana, as well as $S$. repleta. The remaining Schistochila species constitutes clade III. The phylogenetic relationships of the family Schistochilaceae were not fully resolved, but the close affinity between Pleurocladopsis simulans and Schistochila spegazziniana, S. conchophylla and $S$. pinnatifolia was clearly determined.

\section{Discussion}

The result of the present study resolved Pleurocladopsis simulans within the genus Schistochila, with close affinity to the South American Schistochila spegazziniana, and the Australasian $S$. conchophylla and S. pinnatifolia. Interestingly, they fall in the group (clade IV) containing all the southeastern Asian and Oceanian species including S. vitreocincta, and only a few of the Southern Hemisphere, and according to our study it is these species that exhibit the most diverse morphology in the family. Schuster (1971) already pointed out that $P$. simulans shares the unkeeled leaves and the beaked sporophyte capsule with $S$. spegazziniana. The species in clade IV have evolved enormous trigones of cells, larger spores and tortuous elaters, in contrast to the small spores and rigid and nontortuous elaters in the species of clades I and II, and some of clade III. Reduction of the underleaf and evolution of epiphytism have also occurred in many of the species in clade IV. The phylogeny of the family in the present study suggests that these mentioned characters were derived later. Thus our result does not support the longstanding presumption that Pleurocladopsis represents the starting point of evolution in Schistochilaceae. Rather, it uncovers that the genus was established solely based on autapomorphic characters, thus obscuring its actual phylogenetic relationship with Schistochila and that these characters are later derived rather than ancestral. The remarkable autapomorhic evolution in Pleurocladopsis simulans had hindered Massalongo, Stephani as well as Schuster from understanding the species. Our result also confirms that the gynoecial and sporophytic characters are important in leafy liverwort taxonomy, but they may not be sufficient at infrafamilial level and at other lower taxonomic levels. 
Ptilidium pulcherrimum

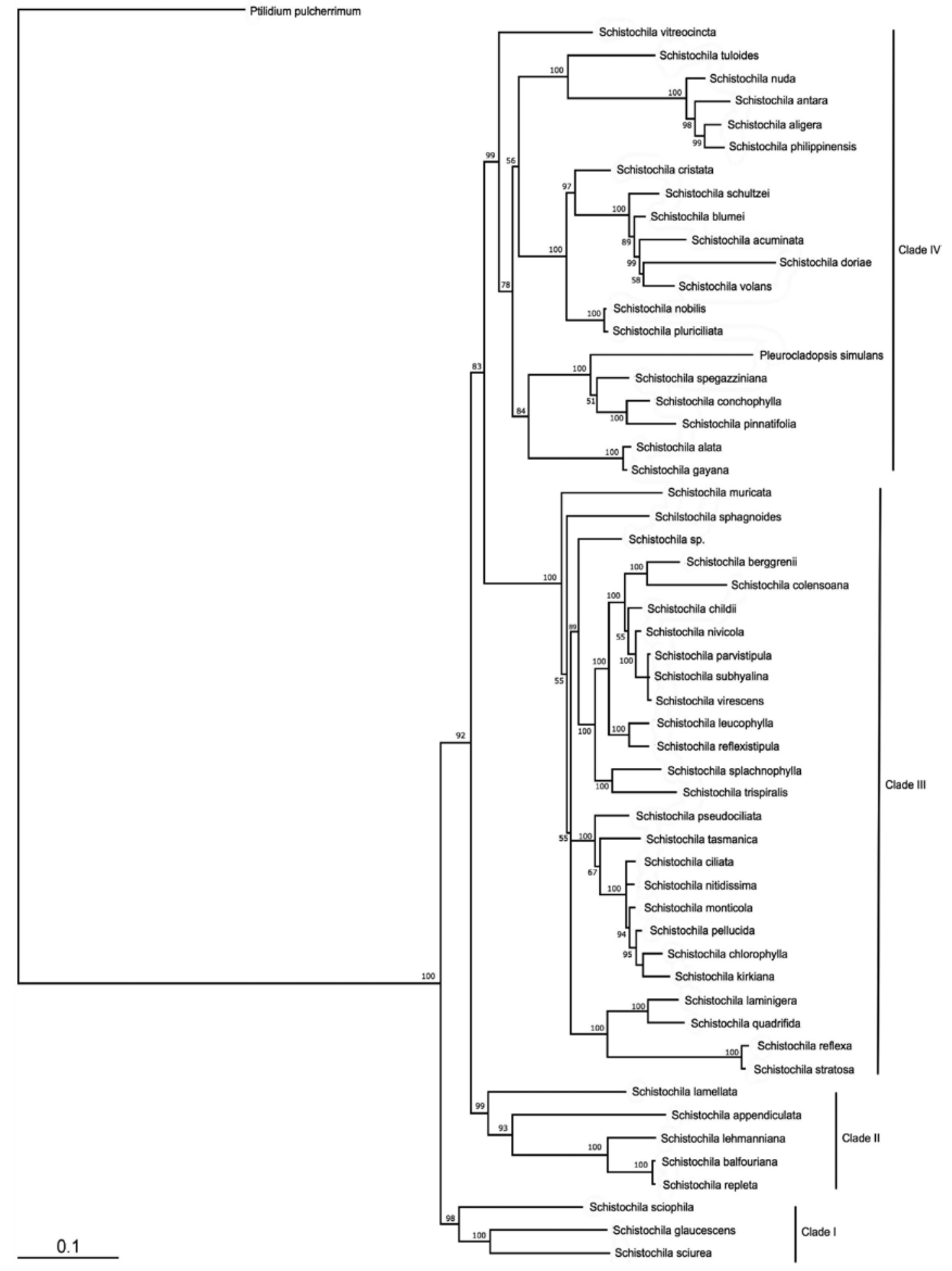


Recently, it has been shown that many genera thought to be stenotypic and established based on series of unique morphological characters are wrongly placed and that those characters are later derived rather than ancestral. Perssoniella of Schistochilaceae (He \& Glenny 2010), Amphilophocolea (Engel et al. 2009) and Cyanolophocolea (Engel \& He 2010) of Lophocoleaceae are examples of temperate Southern Hemisphere genera.

The family Schistochilaceae encompasses ca 80 species and more than two-thirds of the extant species of the family occur in southern South America and temperate to subantarctic Australasia. It has been assumed that the Schistochilaceae originated in Gondwanaland and its dispersal has been predicated on continental drift events (Schuster 1979, 1982; Schuster \& Engel 1977, 1985). Therefore the family has been thought to be extremely old, the extant taxa possibly being survivors from the beginning of Mesozoic which have undergone little change since the beginning of the Tertiary due to being associated with relatively stable higher plant communities. The origin and biogeography of the family will be analysed and discussed in a separate paper.

\section{TAXONOMIC TREATMENT}

In accordance with the results of our study, the following nomenclatural changes are proposed:

\section{Schistochila Dumort.}

Recueil d'Observations sur les Jungermanniacées: 15. 1835. - TYPE: Schistochila appendiculata (Hook.) Dumort. ex Trevis.

$=$ Paraschistochila R. M. Schust., J. Hattori Bot. Lab 26: 259. 1963. - TYPE: Paraschistochila pinnatifolia (Hook.) R. M. Schust.

$=$ Pachyschistochila R. M. Schust. \& J. J. Engel, Phytologia 50: 177. 1982. - TYPE: Pachyschistochila splachnophylla (Hook. f. \& Taylor) R. M. Schust. \& J. J. Engel
$=$ Perssoniella Herzog, Arkiv för Botanik utgivet av K. Svenska Vetenskapsakademien 2: 268. 1952. - TYPE: Perssoniella vitreocincta Herzog

= Schistochilaster H. A. Mill., Phytologia 20: 317. 1970.

- TYPE: Schistochilaster aligera (Nees) H. A. Miller

= Tegulifolium Hässel, Bol. Soc. Argent. Bot. 15: 252. 1973. - TYPE: Tegulifolium spegazzinianum (C. Massal.) Hässel

= Pleurocladopsis R. M. Schust., Nova Hedwigia 8: 279. 1964., syn. nov. - TYPE: Pleurocladopsis simulans (C. Massal.) R. M. Schust.

Schistochila simulans (C. Massal.) Xiao L. He \& Yu Sun, comb. nov.

Cephalozia simulans C. Massal., Nuovo Giorn. Bot. Ital. 17: 236. 1885.

SPECIMEN EXAMINED: CHILE, Prov. ANTÁRTICA Chilena, Comuna Cabo de Hornos, Parque Nacional Alberto de Agostini, South-Central coast of Isla Gordon, Caleta Caracoles, NW of Estero Fouque along Brazo Sudoeste of Beagle Channel at upland lake, $55^{\circ} 02.038^{\prime} \mathrm{S}$, $69^{\circ} 37.015^{\prime} \mathrm{W}$, on dripping cliff wall on ENE shore of smaller lake, X. He $2928(\mathrm{H})$.

ACKNOWLEDGEMENTS. The senior author is grateful to Matt von Konrat and William Buck for offering the opportunity to collect Pleurocladopsis simulans and other bryophytes in the Cape Horn Biosphere Reserve, southern Chile, and we thank David Glenny, Juan Larraín and Neil Bell for providing specimens of Schistochila for this study. The herbaria CONC, H, and GOET are acknowledged for loans for this study.

\section{REFERENCES}

EDGAR R. C. 2004. MUSCLE: multiple sequence alignment with high accuracy and high throughput. Nucleic Acids Research 32: 1792-1797.

Engel J. J. \& He X. 2010. Studies on Lophocoleaceae. XIX. The systematic identity of Cyanolophocolea R. M. Schust., an intriguing liverwort from New Zealand and Australia, based on morphological and molecular evidence. Bryologist 113(1):149-163.

EnGel J. J., HE X. \& GLENNY D. 2009. Studies on Lophocoleaceae XXII. The systematic position of Amphilophocolea

Fig. 1. Phylogenetic relationship of Pleurocladopsis simulans (C. Massal.) R. M. Schust. based on a combined Bayesian analysis of $r b c \mathrm{~L}, r p s 4$ and $t r n \mathrm{~L}-\mathrm{F}$ sequence datasets from 55 exemplars. A $50 \%$ majority-rule consensus tree is presented. Bayesian posterior probabilities $\geq 0.95$ are indicated. Scale bar represents 0.1 substitutions/site. 
R. M. Schust. together with comments on the status of Tetracymbaliella Grolle and Lamellocolea R.M. Schust. Phytotaxa 9: 41-52.

Grolle R. 1972. Namen der Familien und Unterfamilien der Lebermoose (Hepaticopsida). J. Bryol. 7: 201-236.

HÄSSEl De MenÉndez G. G. \& RuBies M. F. 2009. Catalogue of Marchantiophyta and Anthocerotophyta of southern South America. Nova Hedwigia Beih. 134: 1-672.

He X. \& GlenNy D. 2010. Perssoniella and the genera of Schistochilaceae: a new classification based on molecular phylogenies. Austral. Syst. Bot. 23: 229-238

He-NygrÉn X., AhONEn I., Juslén A., GLENNY D. \& PiIPPO S. 2004. Phylogeny of liverworts-beyond a leaf and a thallus. In: B. Goffinet, V. Hollowell \& R. MAGill (eds), Molecular Systematics of Bryophytes. Monogr. Syst. Bot. Missouri Bot. Gard. 98: 87-118.

He-NygRÉn X., JusLÉn A., AhONEn I., GLENNY D. \& PIIPPO S. 2006. Illuminating evolutionary history of liverworts (Marchantiophyta) - towards a natural classification. Cladistics 22: 1-31.

HuElsENBECK J. P. \& RONQUist F. 2001. MRBAYES: Bayesian inference of phylogenetic trees. Bioinformatics Application Note 17: 754-755.

MASSALONGO C. 1885. Epatiche raccolte alla Terra del Fuoco dal Dott. C. Spegazzini nell'anno 1882. Nuovo Giorn. Bot. Ital. 17: 201-277.

NYLANDER J. A. A. 2004. MrModeltest 2.3. Program distributed by the author. Evolutionary Biology Centre, Uppsala University, Uppsala, Sweden.

RONQUIST F. 2004. Bayesian inference of character evolution. Trends Ecol. Evol. 19: 475-481.

Ronquist F., Teslenko M., VAN DER MARK P., Ayres D., Darling A., Höhna S., Larget B., LiU L., Suchard M. A. \& HuELSENBECK J. P. 2012. MrBayes 3.2: Efficient Bayesian phylogenetic inference and model choice across a large model space. Syst. Biol. 61: 1-4.
SCHUSTER R. M. 1964a. Studies on Hepaticae XXII-XXV. Pleurocladopsis Schust. gen. n., Eoisotachis Schust. gen. n., Grollea Schust. gen. n., with critical notes on Anthelia Dumort. Nova Hedwigia 8(3/4): 275-296.

SCHUSTER R. M. 1964b. Studies on Antipodal Hepaticae VI. The suborder Perssoniellinae: morphology, anatomy and possible evolution. Bull. Torrey Bot. Club 91: 479-490.

SCHUSTER R. M. 1966. The Hepaticae and Anthocerotae of North America, East of Hundredth Meridian. 1. Columbia Univ. Press, New York.

SCHUSTER R. M. 1971. On the genus Pleurocladopsis Schust. (Schistochilaceae). Bryologist 74(4): 493-495.

SCHUSTER R. M. 1972. Phylogenetic and taxonomic studies on Jungermanniidae. J. Hattori Bot. Lab. 36: 321-405.

SCHUSTER R. M. 1979. On the persistence and dispersal of transantarctic Hepaticae. Canad. J. Bot. 57: 2179-2225.

SCHUSTER R. M. 1982. Generic and familial endemism in the hepatic flora of Gondwanaland: origins and causes. J. Hattori Bot. Lab. 52: 3-35.

SChuster R. M. \& ENGEL J. J. 1977. Austral Hepaticae, V. The Schistochilaceae of South America. J. Hattori Bot. Lab. 42: 273-423.

SCHuster R. M. \& ENGEL J. J. 1985. Austral Hepaticae V(2). Temperate and subantarctic Schistochilaceae of Australasia. J. Hattori Bot. Lab. 58: 255-539.

SOLARI S. S. 1971. Presencia de celocaule en Pleurocladopsis. Comun. Mus. Argent. Ci. Nat. "B. Rivadavia”, Ci. Bot. 2(4): 15-20.

StePHANI F. 1898-1924. Species Hepaticarum. 1-6. Geneve et Bale, Lyon.

SwOFFORD D. L. 2002. PAUP*. Phylogenetic Analysis Using Parsimony (*and Other Methods). Sinauer Associates, Sunderland MA. 